\title{
THE YOUTH LABOUR MARKET IN NEW ZEALAND - A COMPARISON TO THE PRE-RECESSION SITUATION
}

\author{
Andrea Fromm and Sophie Flynn
}

\author{
Statistics New Zealand
}

\begin{abstract}
Historically, youth have difficulties in succeeding in the labour market. They can struggle with successfully making the transition from school to work and securing a decent job. The problem of competing and succeeding in the labour market for youth has worsened since the recession in 2008. This paper describes the labour market performance of youth prior to and after the recession. The suite of labour market indicators for youth - including the youth not in employment, education or training (NEET) indicator - derived from the cross-sectional Household Labour Force Survey is used to describe and analyse changes before and after 2008. The description is complemented by highlighting significant risk factors in the youth labour market. The overview of the New Zealand youth labour market together with the odds ratio analysis provides an understanding of the changing labour market situation for youth as well as an insight into which sections of youth particularly struggle in the labour market.
\end{abstract}

\section{Introduction}

The purpose of this paper is to increase the understanding of the youth labour market in New Zealand.

Since the global financial crisis in 2008, there has been increasing awareness and debate about young people's (15-24-years-old) difficulties and choices to compete and succeed in the labour market. The global picture of daunting prospects for youth's employment is mirrored by the challenges youth face in the New Zealand labour market.

Guy Ryder, the General Secretary of the International Labour Organisation (ILO), recently blogged that '[g]lobal youth unemployment has become a reservoir of wasted talent and a tinderbox of frustration' (Ryder 2012). Worldwide, nearly 75 million young people are unemployed with an unemployment rate of 12.6 percent. In New Zealand, 62,000 young people were unemployed in the June 2012 quarter. This is nearly twice as many as in the December 2007 quarter.

Youth are commonly hit harder by economic crises due to a lack of overall economic growth, aggregate demand, and employability issues (ILO 2005). The ILO expressed fears that a 'lost generation' might be a possible legacy of the crisis, building an unstable foundation for the economies and societies of today and tomorrow. The resolution and conclusions of the 101st Session of the International Labour Conference (ILC) highlight that a lack of decent work ${ }^{1}$ "can result in long-lasting "scarring” effects on youth’ (ILO 2010). Poor employment prospects and working conditions could potentially continue beyond the age of 25 years.
The European Foundation for the Improvement of Living and Working Conditions (here after Eurofound) estimates that, for instance, the United Kingdom's total cost of youth not in employment, education or training (NEET) is 13.0 billion Euros per year (Eurofound 2011)². Young NEETs on average also have a lower level of institutional trust than youth who are in employment, education or training (EETs) (Eurofound 2011). Young NEETs are less interested in politics, less likely to vote, and less likely to participate in voluntary work than EETs. On this basis, Eurofound concludes that ' $(. .$.$) as a group [NEETs]$ are at a higher risk of disaffection and more likely to withdraw from society’ (Eurofound 2011).

A thematic review of policies to facilitate the transition from school to work and to improve the career perspectives of youth, concludes that '[t]he recent performance of the youth labour market in New Zealand is very good compared with many other OECD countries' (OECD 2008). However, in the same paragraph, the OECD warns that 'the current economic slow-down is likely to reveal some remaining weaknesses in the youth labour market that need to be addressed' (OECD 2008).

The analysis and comparison of the data from the Household Labour Force Survey (HLFS) before and after 2008 investigates this further. This paper covers:

1) introduction and measurement of youth labour markets

2) description of the New Zealand youth labour market prior to and after 2008 and confirmation of the descriptive statistics with an odds ratio analysis 
3) conclusion on effects of the global financial crisis on the New Zealand youth labour market.

\section{How to Measure the Youth Labour Market}

The 'traditional' indicators used to understand youth labour markets are the youth labour force participation rate, youth employment rate, and youth unemployment rate:

- $\quad$ youth labour force participation rate measures the proportion of the total youth population who participate in the labour force, meaning they are either employed or unemployed

- youth employment rate shows the proportion of the total youth population who are employed for one hour or more

- youth unemployment rate indicates the proportion of youth in the labour force who are without paid work, are available and actively seeking work.

Due to the large number of youth in education or training, these 'traditional' labour market indicators have some limitations when trying to assess the state of youth labour markets. Of the relatively high number of youth not in the labour force, a large proportion are in education or training, or they are, for some other reason, not available for work and/or do not actively seek work. Additionally, a significant proportion of unemployed youth are in education or training. These youth who are unemployed and in education or training could be less at risk of poor outcomes in the future. They could also be less of a labour underutilisation issue as they are increasing their potential through engagement with education.

For these reasons, an indicator that considers young people's labour market participation, together with their engagement in education or training, can be a useful complementary indicator of potential youth labour underutilisation. It can also be a useful first step in identifying youth who may be at higher risk of poor outcomes in the future.

The NEET rate is commonly used to measure non-utilised youth labour potential and, as stated above, youth who are at risk of becoming disadvantaged or marginalised in the future. In the March 2004 quarter the HLFS introduced questions on participation in education enabling the official measurement of NEET. The NEET rate is calculated as follows:

Although NEET includes youth who undertake other activities that are beneficial to their well-being and youth who are in a transition period it is still a useful complementary indicator to the suite of traditional youth labour market indicators.

The ILO explains that youth NEET is a measure of youth who are not employed and is therefore, a 'broader measure of potential youth labour market entrants than youth unemployment' (ILO 2012a). The OECD highlights that 'the proportion of youth neither in education, nor in employment or training (NEET) provides another key indicator of labour market performance for youth because this is a group at high risk of labour market marginalisation and social exclusion' (Quintini and Martin, 2006).

Youth who are NEET have diverse experiences, characteristics, difficulties, needs, or make distinct choices (Yates and Payne 2006). They may choose not to be in the labour force due to reasons such as looking after children, travelling, or volunteering. Others have limited control over not being in the labour force due to reasons such as a lack of jobs, disability, long-term sickness, poor qualifications, substance abuse, or criminal offences (Furlong 2007). The youth NEET indicator is used in the subsequent analysis to complement and facilitate better understanding of the youth labour market.

\section{The New Zealand Youth Labour Market}

Youth form a distinct group of people among the working-age population. After school or education, most youth seek formal and longer-term employment. Some youth might have gained work experience during their school or study time through casual and part-time jobs. The ILO and Statistics NZ define youth as people aged 15-24 years. However, boundaries between youth and adulthood, and school and work are becoming increasingly blurred. Defining youth as the group below 25 years of age might underreport school to work transition difficulties. Students in tertiary education in New Zealand are older now than they used to be (Ministry of Education 2006) ${ }^{3}$. Moreover, defining youth as the group below 25 years might underreport on young women's maternity to work transition difficulties because women now tend to have children later in life (Statistics NZ 2012) ${ }^{4}$. Policy changes such as the introduction of the New Entrants (NE) minimum wage in $2008^{5}$ as well as welfare reform changes at the beginning of 2012 had and will have an impact on the youth labour market. While the relationships and impacts of the societal and policyrelated developments are difficult to unpick, they require further research.

The business cycle, structural components, and institutional effects are among the main drivers of youth labour markets creating either opportunities or difficulties for youth. During 2008, economic activity in New Zealand decreased as measured by the gross domestic product (GDP). The two labour market diagrams (figures 1 and 2) show the youth labour market in December 2007 and in June 2012. They are seasonally adjusted and therefore comparable. 
Figure 1: Youth labour market, December 2007 quarter, seasonally adjusted figures
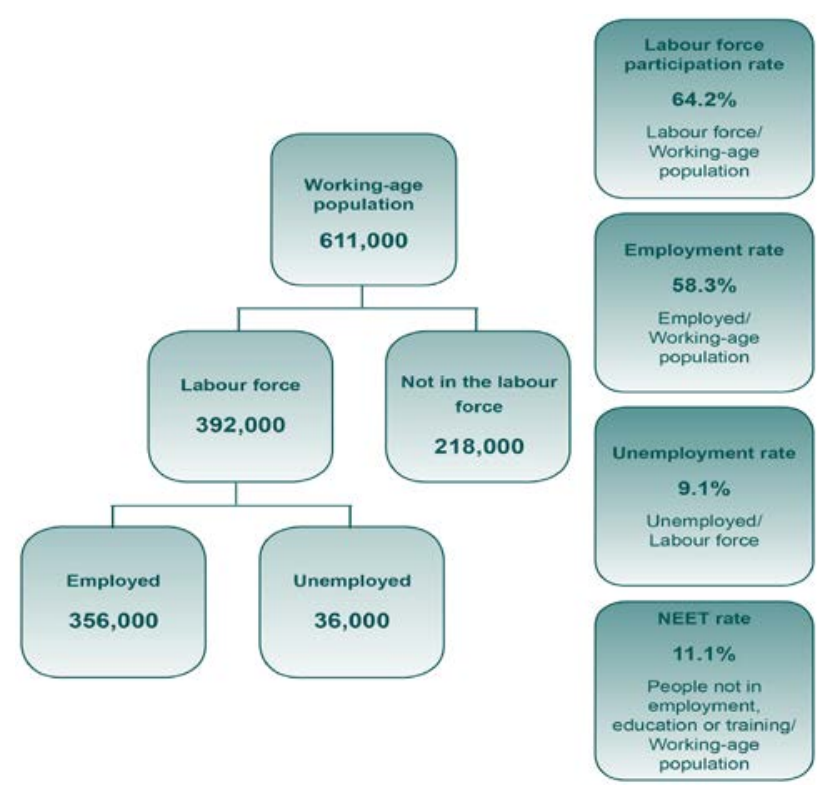

Figure 2: Youth labour market, June 2012 quarter, seasonally adjusted figures
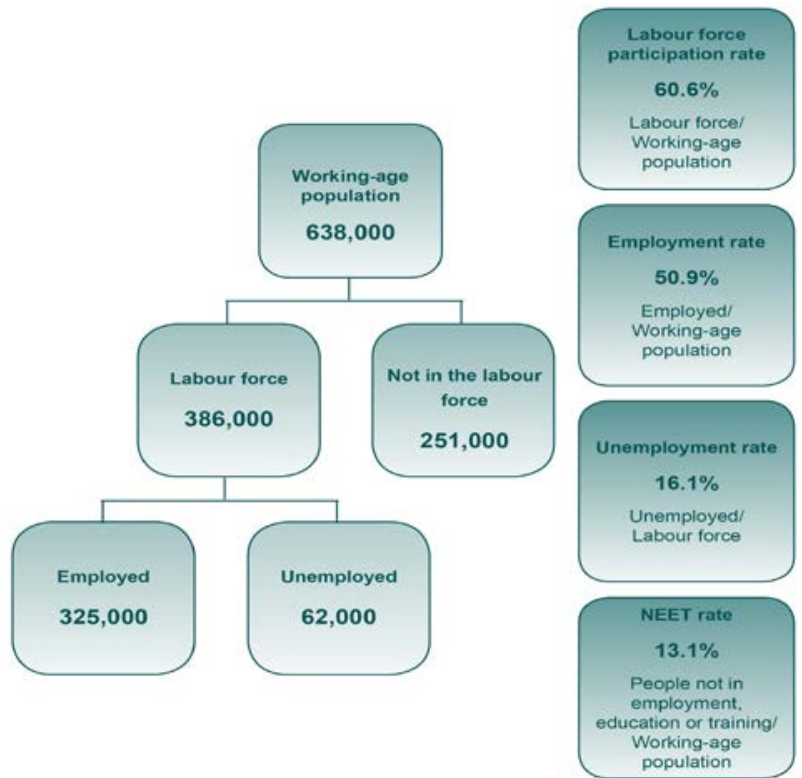

The December 2007 quarter was chosen as the reference quarter to compare the current youth labour market to the pre-recession economic climate. This quarter was chosen because it was the last quarter of economic growth (as measured by GDP) in New Zealand, before decreasing for six consecutive quarters in 2008 and 2009.

\section{The Young Labour Force in New Zealand Before and After 2008}

The graphs in this section illustrate changes in the youth labour force from the December 2007 quarter to the June 2012 quarter. The data is seasonally adjusted.

The graphs show that the recession played out differently for youth when compared with the rest of the labour force. Employment fell and unemployment rose for both, youth and those over 25 years, but youth were hit harder than those 25 years and over. In contrast the labour force participation rate (LFPR) decreased for youth while it increased for those over 25 years.

Figure 3 and figure 4 show that the effect on youth employment rates and youth unemployment rates was more noticeable. For the labour force over 25 years old employment and unemployment rates levelled off earlier than young people's employment and unemployment rates. The employment and unemployment rates of those over 25 years stabilised in the December 2009 quarter. The employment rate for youth started to level off around the same time but experienced a much faster and drastic fall from the December 2008 quarter. Between the December 2007 quarter and the December 2009 quarter the youth employment rate fell from 58.3 percent to 49.9 percent (down 8.4 percentage points). In contrast the employment rate for those over 25 years decreased from 67.8 percent to 66.6 percent (down 1.2 percentage points).

\section{Figure 3}



Source: Statistics New Zealand

Comparable to the employment rate, the unemployment rate for youth increased at a faster pace as shown by figure 4: it rose from 9.1 percent in the December 2007 quarter to 19.2 percent in the December 2009 quarter (up 10.1 percentage points) which is the highest level since the September quarter in 1992. 


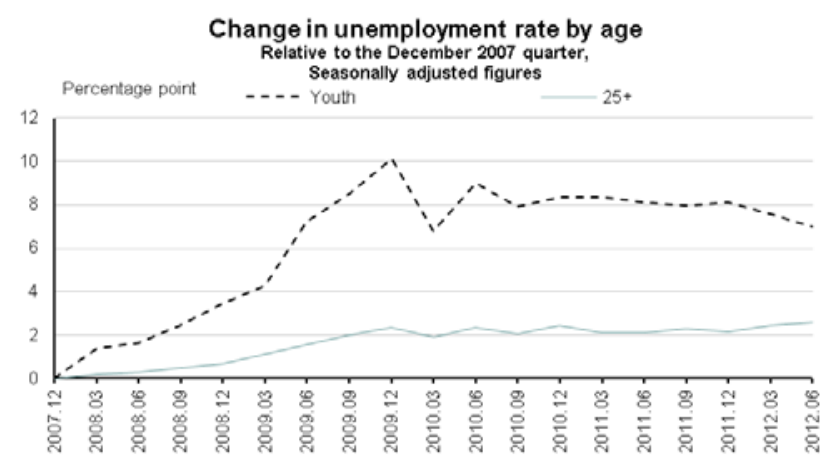

Source: Statistics New Zealand

The gap between employment rates of youth and those over 25 years and of unemployment rates of youth and those over 25 years remains wide. However, the employment rates of both age groups and unemployment rates of both age groups have come closer together in the last two quarters.

The unemployment rate for youth is typically higher than for those over 25 years and tends to increase more rapidly during economic downturn. In times of recovery, the youth unemployment rate is usually slower to decrease. Figure 5 shows that the unemployment rate for youth in the recent recession increased strongly.

\section{Figure 5}



Source: Statistics New Zealan

The ratio of the youth unemployment rate to the unemployment rate of those over 25 years (figure 6) is relatively stable until the end of 2004 but increased considerably in subsequent years. From the March 1986 quarter to the December 2004 quarter, the ratio was $3: 1$ on average. From the March quarter 2005 to the June quarter 2012, the ratio of the youth unemployment rate to the unemployment rate of those over 25 years increased to $4: 1$ on average. This illustrates that by comparison with the recessions of the $1990 s^{6}$ the global financial crisis had a greater affect on youth unemployment rates relative to that of those aged over 25 years.
Figure 6

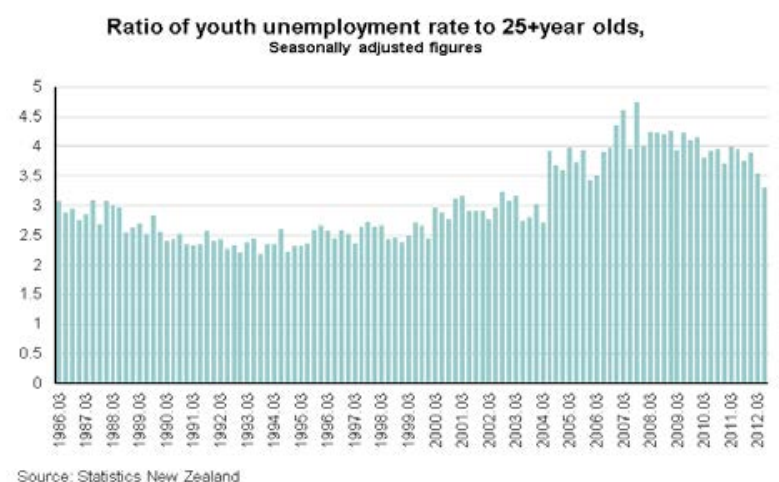

The LFPR shown in figure 7 reveals different movements in the proportions of youth and those over 25 years in the labour force. While the LFPR for those over 25 years was barely affected and increased beyond pre-recessionary levels, the LFPR for youth fell to and remains well below pre-recessionary levels.

\section{Figure 7}

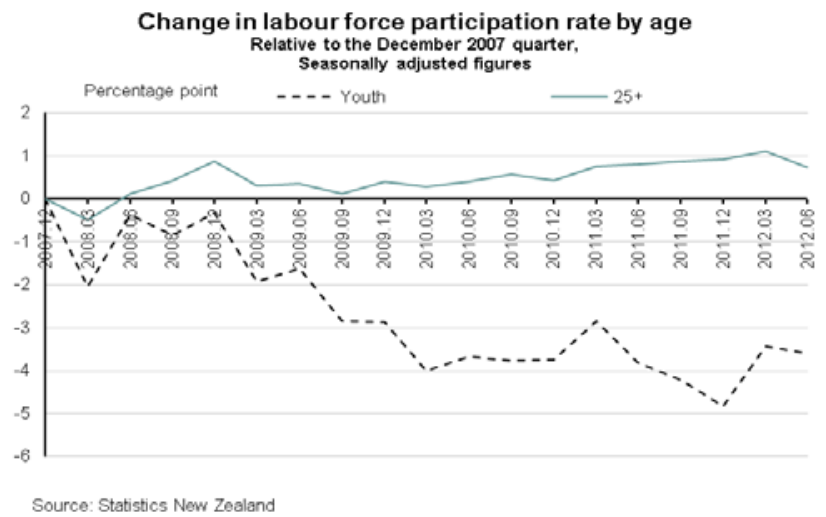

The particular acceleration of the youth unemployment rate and decrease of the LFPR of youth poses several questions. Are more people who are studying also looking and available for work, and if so are they seeking parttime or full-time work? Are an increasing number of youth studying? Can we better understand youth who are not in employment, education or training? Are groups of youth particularly affected by the recession? These questions will be answered below.

\section{Who Are the Unemployed Youth?}

The youth unemployment rate may be misleading in assessing the youth labour market because a significant proportion of young unemployed people are in education. For instance, youth who are available for and are seeking part-time employment while being at school or studying might be less at risk of poor labour market outcomes. Hence this section will provide information on who the unemployed youth are, whether they are in education or 
not, and whether they are looking for part-time or fulltime work.

Youth unemployment rates show differences among different groups of youth. Commonly, the unemployment rate for 15-19-year-olds is higher than the unemployment rate for those aged 20-24 years (figure 8). For both age groups the unemployment rate has risen since the December 2007 quarter. One year later in the December 2008 quarter the increases in the unemployment rates for both groups accelerated, but at a faster pace for 15-19years-old.

\section{Figure 8}

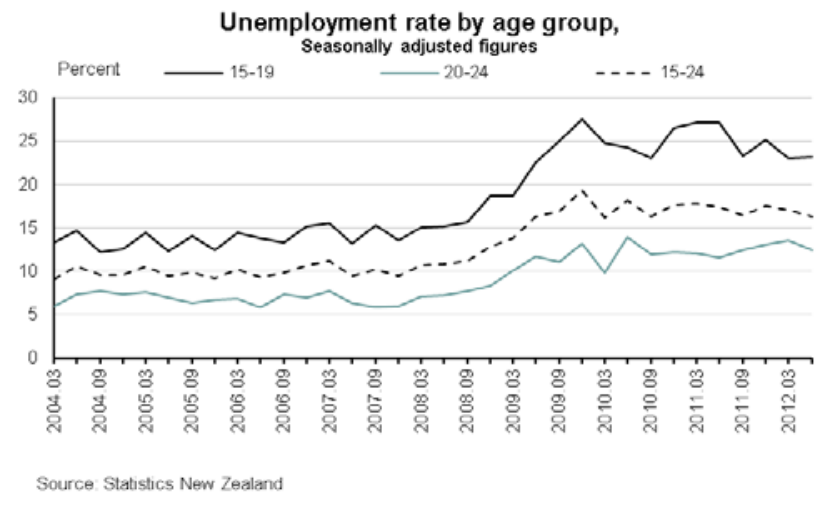

The youth unemployment rate of both men and women moves in the same direction (figure 9). Male unemployment rates tend to be slightly higher than female unemployment rates and this was especially the case in the 2009 and 2011 years.

\section{Figure 9}

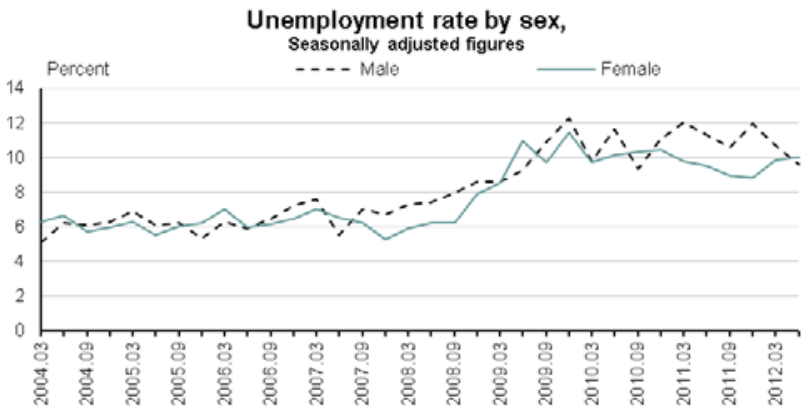

Source: Statistics New Zealand

To get a deeper understanding of youth who are not using their full potential in the labour market, figures 10 and 11 illustrate the number of unemployed youth by age group and education status, plus if they are seeking part-time or full-time employment. The data is unadjusted.

As expected, when looking at 15-19-year-old unemployed people, those looking for part-time employment are more likely to be in education while those looking for full-time employment are more likely not to be in education (figure 10). Both the number of 1519-year-olds seeking full-time employment or part-time employment increased at the beginning of 2008. Between the December 2007 and 2011 years, the largest increases in unemployment for 15-19-year-olds were among those in education seeking part-time employment (up 5,600), and those not in education seeking full-time employment (up 3,700).

\section{Figure 10}

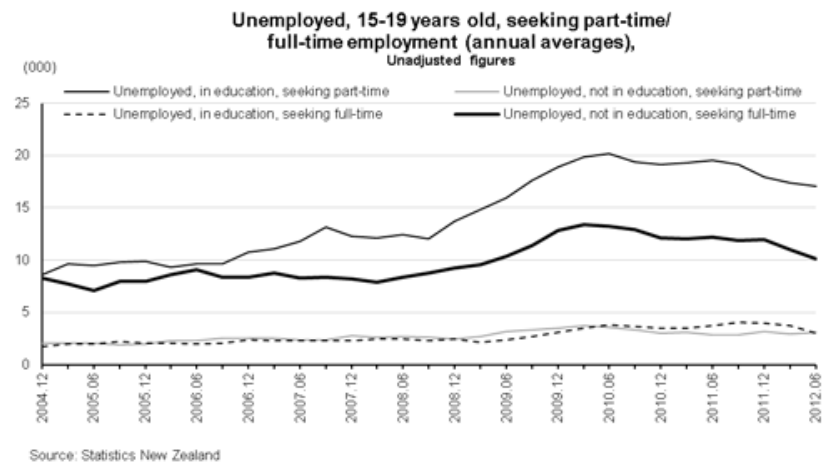

More unemployed 20-24-year-olds, who are not in education seek full-time employment compared to parttime work (figure 11). Both the number of 20-24-yearolds and the number of 15-19-year-olds unemployed people seeking full-time or part-time employment increased at the beginning of 2008 .

\section{Figure 11}

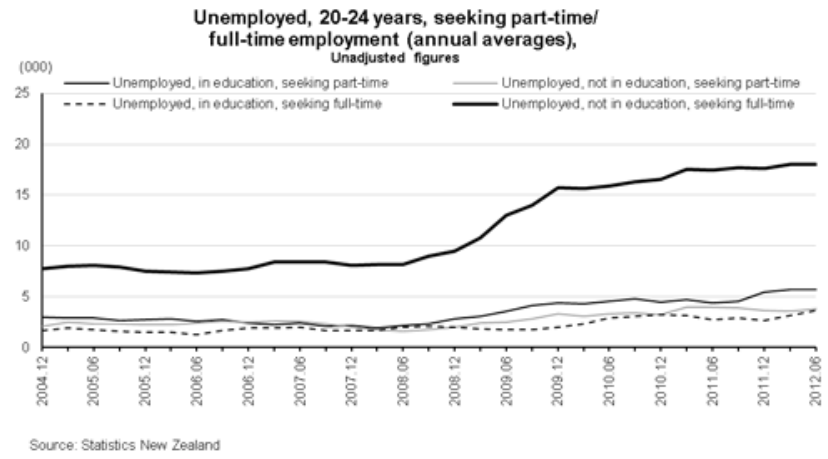

The global financial crisis of 2008 did not change the fact that among the youth population usually a higher proportion of 15-19-year-olds and young men are unemployed. The financial crisis also did not change the fact that both 15-19 and 20-24-year-olds, are more likely to be seeking part-time employment while studying and to be seeking full-time employment when they are not studying. What the financial crisis did change is the magnitude of youth unemployment for both age groups, for both sexes, whether they are in education or not and whether they are seeking part-time or full-time employment. 


\section{Developments in the Youth Labour Market}

It is impossible to accurately analyse the youth labour market by only looking at the youth labour force. Youth who are not in the labour force should also be taken into regard in order to fully understand the youth labour market. Of the relatively high number of youth who are not in the labour force a considerable proportion are in education or training, or they are, for some other reason, not available for work and/or do not actively seek work.

Therefore the analysis will first look at youth who are not in the labour force and are in education to answer the question of whether the number of youth solely engaged in education or training increased or decreased.

Second, the analysis will use the NEET indicator to consider youth's labour market participation, together with their engagement in education or training. It can be a useful first step in identifying youth who may be at higher risk of poor outcomes in the future.

While the proportion of youth who are not in the labour force and in education increased for 15-19-year-olds, the total proportion of youth in this situation has remained relatively flat since the global financial crisis of 2008 (figure 12). More 20-24-year-olds are at a higher risk of poor labour market outcomes because:

- the proportion of 20-24-year-olds who solely study remained relatively stable while the proportion of 15-19-year-olds increased, and

- the proportion of 20-24-year-olds who are unemployed (and not in education) and seeking full-time work increased while the proportion of 15-19-year-olds remained relatively flat.

\section{Figure 12}

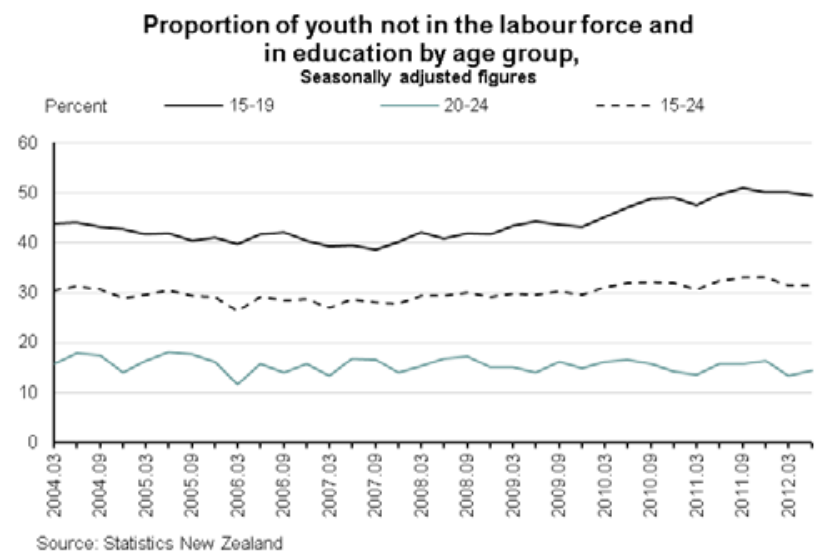

This is also seen in the NEET rate. The NEET rate for the 20-24-year-olds is higher than the NEET rate for the 1519-year-olds. Between the December 2007 quarter and the June 2012 quarter, the NEET rate for 20-24-year-olds increased from 14.3 percent to 17.1 percent (up 2.8 percentage points) while the NEET rate for 15-19-yearolds increased slightly from 8.2 percent to 8.9 percent (up 0.7 percentage point).

Figure 13 clearly illustrates that the total NEET rate in the quarters of the year 2008 increased considerably compared with the year 2007. Despite subsequent fluctuations the NEET rates are still higher than prerecession levels: in the December 2007 quarter the total youth NEET rate was 11.1 percent and by the June 2012 quarter it had increased to 13.1 percent. The NEET rate reached its peak in the December 2009 quarter at 15.4 percent.

This seems a relatively minor increase compared with the youth unemployment rate. However, it is important to remember that the NEET rate is calculated over the working-age population while the unemployment rate is calculated over the labour force. In the December 2007 quarter the youth unemployment rate was 9.4 percent and by the June 2012 quarter it had increased to 16.3 percent. The youth unemployment rate reached its peak in the December 2009 quarter at 19.3 percent.

\section{Figure 13}

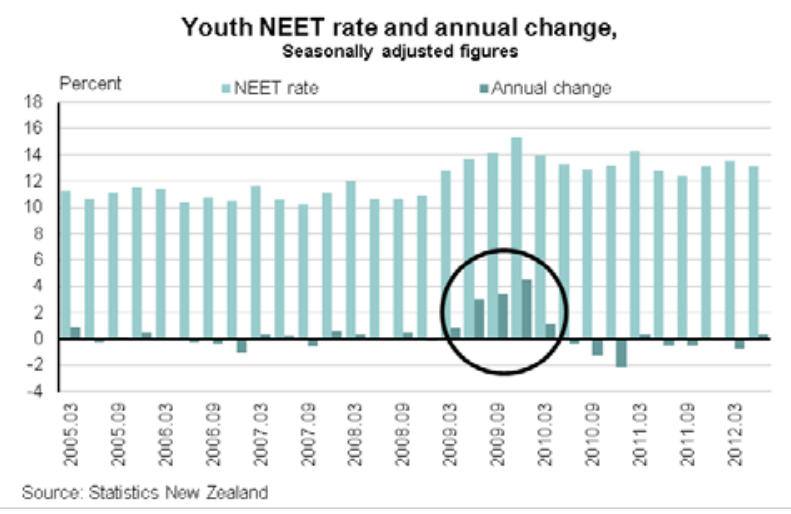

The NEET rate confirms that a larger proportion of youth are at higher risk of poor labour market outcomes since the global financial crisis of 2008. A proportion of youth NEET are unemployed, not in education and seeking fulltime work. Who are these young people who are at higher risk of poor outcomes in the future?

Youth NEET rates are higher for women than for men (figure 14). A key factor in this is that a larger proportion of women than men who are not in the labour force and not in education are engaged in caregiving. Both men and women were affected by the increase in NEET rates after 2008. 


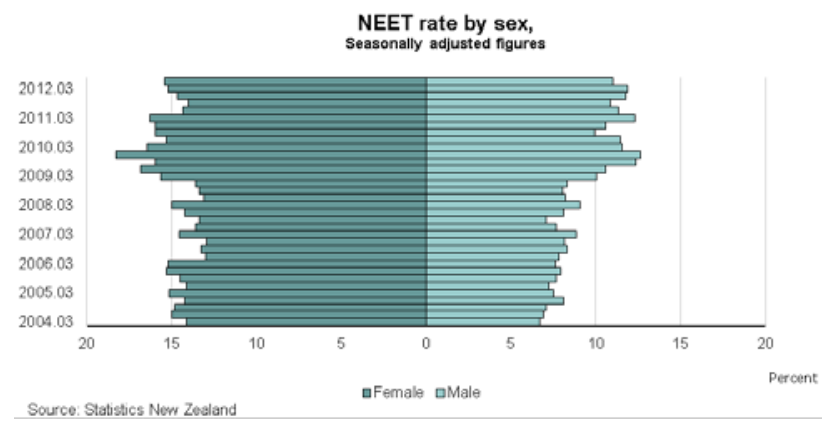

The following analysis uses unadjusted data. All ethnic groups except for Māori saw an increase in their NEET rates in December 2011 when compared to December 2007. The NEET rate for Māori was relatively flat at 21.1 percent (down 0.1 percentage point) but had the highest NEET rate in both, the December 2007 and December 2011 quarter. Pacific peoples experienced the greatest rise of 4.1 percentage points (13.7 to 17.8 percent) between the December 2007 and 2011 quarters, while Europeans had the second-highest increase of 2.3 percentage points (8.8 to 11.1 percent). The NEET rate for Asians increased by 2.1 percentage points to 10.1 percent.

\section{Figure 15}

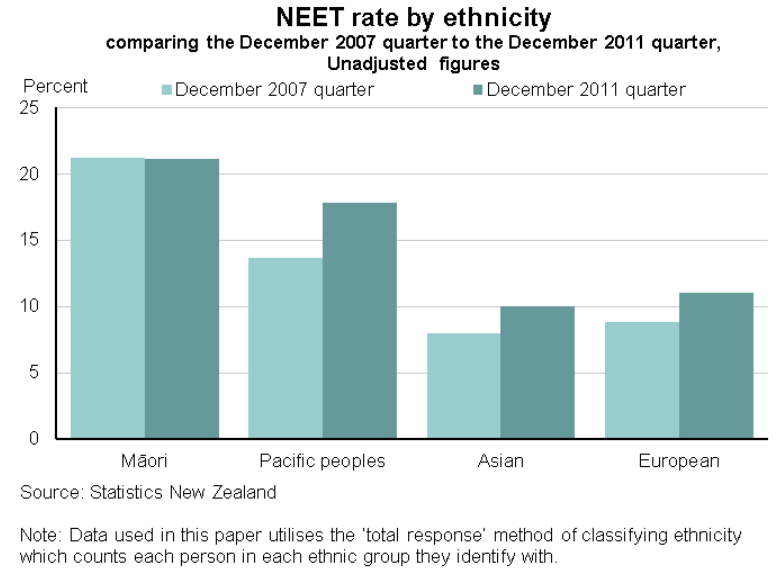

The qualification levels of youth show that youth without qualifications are most likely to be NEET (Tables 1 and 2). Youth who are employed (whether they are in education or not) are more likely to have at least a school qualification. However, a higher proportion of unemployed youth who are not in education had school and post-school qualifications in the December 2011 quarter than in the December 2007 quarter.

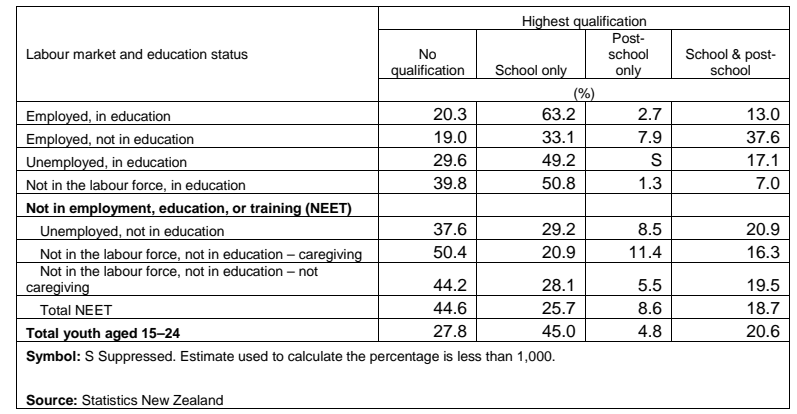

Table 2: December 2011 quarter, unadjusted figures

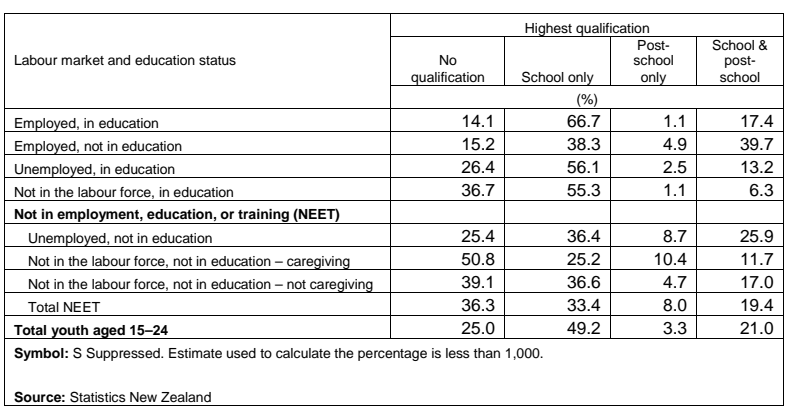

The analysis above shows that the NEET rate increased substantially in 2008 and is yet to recover back to prerecession levels. Both age groups, men and women, and all ethnic groups, experienced increases in their NEET rates. This is more severe for those groups who are more likely to be NEET regardless of economic downturns: the 20-24-year-olds, women and Māori.

Although it is still more likely that a young person who is NEET has no qualifications, more young people are unemployed (and not in education) who have school and post-school qualifications. This means that in the current labour market a qualification is less of a guarantee to find employment.

\section{Risk Factors in the Youth Labour Market}

The descriptive statistics have shown a deteriorating labour market situation for youth since the December 2007 quarter. Conducting a weighted logistic regression analysis, or an odds ratio analysis, confirms the hypothesis gained from the descriptive statistics that the recession had an impact on youth in New Zealand. The analysis shows the risk of not being employed for youth and those over 25 years in the December 2007 quarter and the December 2011 quarter. The analysis also shows the risk of being NEET for different groups of youth in the December 2011 quarter.

The odds ratio is the odds of being $\mathrm{X}$ for one group divided by the odds of being $\mathrm{Y}$ for another group. An odds ratio of 1 indicates that the odds of an outcome are equally likely for both groups under comparison. The 
relationship becomes stronger the more the estimate deviates from 1 . For instance, the odds ratio of not being employed of youth compared to those over 25 is 2.08, or twice as high, in the December 2011quarter.

Multiple regression analysis found that being a young person is a significant risk factor for not being employed. Between the December 2007 and December 2011 quarter, the risk of not being employed for youth increased significantly. This result confirms that the global financial crisis had an impact on young people's success in the labour market. The results reported use unadjusted survey data.

\section{Table 3}

\begin{tabular}{|l|r|r|r|r|r|r|}
\hline \multicolumn{6}{|c|}{ Odds ratio estimates not employed, Unadjusted figures } \\
\hline Explanatory variable & \multicolumn{2}{|c|}{ December 2007 quarter } & \multicolumn{2}{|c|}{ December 2011 quarter } \\
\hline & Estimate & \multicolumn{2}{c|}{$95 \% \mathrm{Cl}$} & Estimate & $95 \% \mathrm{Cl}$ \\
\hline $15-24$ vs $25+$ & 1.43 & 1.30 & 1.57 & 2.08 & 1.89 & 2.28 \\
\hline
\end{tabular}

Significant risk factors for being NEET include being 2024-years-old, being female, being of Māori ethnicity, and having no qualification or school only qualification. Between the December 2007 and December 2011 quarter, the risk of being NEET for 20-24-years-old, women, Māori and those having no qualification or a school only qualification did not significantly change.

The 20-24-year-olds are more than twice as likely to be NEET as the 15-19-year-olds. The odds ratio of being NEET for women compared to men is 1.58. The risk of being NEET of Māori youth compared to youth who do not identify with Māori ethnicity is twice as high. Having no qualification compared to having school and postschool qualification increases the risk of a young person to be NEET by nearly three times. These results confirm what was shown earlier in this paper: age, sex, ethnicity and qualification are significant risk factors for being NEET.

\section{Table 4}

\begin{tabular}{|l|r|r|r|}
\hline Odds ratio estimates NEET, Unadjusted figures \\
\hline Explanatory variable & \multicolumn{3}{|c|}{ December 2011 quarter } \\
\hline & Estimate & $95 \% \mathrm{Cl}$ \\
\hline $20-24$ vs 15-19 & 2.68 & 2.09 & 3.42 \\
\hline Female vs male & 1.58 & 1.29 & 1.95 \\
\hline Māori vs Non-Māori & 2.00 & 1.60 & 2.51 \\
\hline No qualification vs School \& post-school & 2.78 & 1.97 & 3.92 \\
\hline
\end{tabular}

\section{Conclusion}

The paper has shown that the economic conditions since 2008 have had a strong impact on the New Zealand labour market, and particularly on the youth labour market. Although employment rates have fallen and unemployment rates have risen for both youth and for those over 25 years, the current labour market for youth lacks considerable movement back to pre-recession levels. The decrease in the employment rate and the increase in the unemployment rate relative to the
December 2007 quarter were more marked for youth than for those over 25 years.

The analysis distinguished between young unemployed people and young people who are not in the labour force in relation to their attachment to education. The analysis has shown that more 20-24-year-olds are at a higher risk of poor labour market outcomes because:

- the proportion of 20-24-year-olds who solely study remained relatively stable while the proportion of 15-19-year-olds increased, and

- the proportion of 20-24-year-olds who are unemployed (and not in education) and seeking full-time work increased while the proportion of 15-19-year-olds remained relatively flat.

The analysis then focused on youth who are not in employment, education or training. It was shown that the NEET rate increased substantially in the 2008 year compared to the previous year and is yet to recover back to pre-recession levels. Both age groups, men and women and certain ethnic groups experienced an increase in their NEET rates.

This development is particularly severe for those groups who are more likely to be NEET regardless of economic downturns: the 20-24-year-olds, women and Māori. Although it is still more likely that a young person is NEET who has no qualifications, more young people are unemployed (and not in education) who have school and post-school qualifications. This means that in the current labour market a qualification is less of a guarantee to find employment.

The odds ratio analysis supported that being a young person is a significant risk factor for not being employed when compared to people who are over 25 years. Multiple regression also confirmed that certain sections of youth were at significant risk of being NEET: the 20-24year-olds, women, Māori and those having no qualification or a school only qualification.

The OECD was correct when warning about 'remaining weaknesses in the youth labour market' (OECD 2008). Further research is required to determine exactly what these weaknesses are and how to improve the youth labour market in New Zealand.

\section{Notes}

1. The primary goal of the ILO is to promote opportunities for women and men to obtain decent and productive work, in conditions of freedom, equity, security, and human dignity. Decent Work is defined as the converging focus of all its four strategic objectives: the promotion of rights at work; employment; social protection; and social dialogue. The primary goal of the ILO is to promote opportunities for women and men to obtain decent and productive work, in 
conditions of freedom, equity, security, and human dignity (Somavia 1999).

2. The cost of being NEET is the sum of the resources costs (foregone earnings) and public finance costs (excess transfer). Note that youth NEET are defined as people aged 16-29 yearolds (Eurofound 2011).

3. According to a report published in 2006 by the Ministry of Education, 'the average age of students is nearly five years higher than 1995 (...). While 50 percent of students were aged under 25 in 1995, 38 percent were under 25 in 2005.'

4. According to Statistics NZ, women aged 30-34 years had the highest fertility rate in 2012, while women aged 20-24 years had the highest fertility rate in the 1960s. Generally women in all age groups now have fewer babies (Statistics NZ 2012).

5. For an analysis of the impacts of the New Entrant minimum wage refer to the paper 'The Impact of the 2008 Youth Minimum Wage Reform’ (Department of Labour 2011).

6. One of the 'most complex' recessions New Zealand experienced was the stagnation of the Real Gross Domestic Product (GDP) per capita from 1985 to the beginning of the 1990s. The foreign exchange crisis triggered radical economic reforms, which dislocated economic activities in a new market environment. GDP increased since 1993. In 1997, the Asian Financial Crisis adversely affected the economic performance of countries such as South Korea, Thailand, Taiwan and the Philippines. Since these are important export markets for NewZealand, this crisis caused exports to fall and, as a consequence, another recession (Lattimore and Eaqub 2011).

\section{References}

Blog of the ILO: Promoting jobs and protecting people, Ryder, G. (2012). Helping youth get jobs: A sound investment, at http://iloblog.org/2012/10/01/helping-youth-getjobs-a-sound-investment/

Department of Labour (2011). The Impact of the 2008 Youth Minimum Wage Reform. Wellington: Department of Labour.

Eurofound (2011). Youth and NEETs in Europe: First findings. Brussels: Eurofound, 4-6

Furlong, A. (2007). The Zone of Precarity and Discourses of Vulnerability: NEET in the UK. The Journal of Social Sciences and Humanities (Jinbun Gakuho), 381, 101-121.

International Labour Office (2005). Youth: Pathways to Decent Work. Promoting Youth Employment Tackling the Challenge. Geneva: International Labour Office, 8-10.
International Labour Office (2012). The youth employment crisis: A call for action. Resolution and conclusion of the International Labour Conference. Geneva: International Labour Office, 3.

International Labour Organization (2010). Global Employment Trends for Youth. Special Issue on the Impact of the Global Economic Crisis on Youth. Geneva: International Labour Organization, 1.

International Labour Organization (2012a). Decent Work Indicators - Concepts and Definitions. ILO Manul, First Version. Geneva: International Labour Organization, 51.

Lattimore, R. and Eaqub, S. (2011). The New Zealand Economy: An Introduction, Auckland: Auckland University Press, 4.

Ministry of Education (2006). Older Students. Available from www.educationcounts.govt.nz/

Organisation for Economic Cooperation and Development (2008). Jobs for Youth (Des emplois pour les jeunes): New Zealand. Paris: Organisation for Economic Co-operation and Development, 9.

Quintini, G. and Martin, S. (2006). Starting Well or Losing Their Way? The Position of Youth in the Labour Market in OECD Countries. Paris: OECD, 8.

Somavia, J. (1999) Report of the Director-General to the 87th Session of the ILC - Decent Work. Geneva: ILO, 1999, Accessed 6th June 2010 from http://www.ilo.org/public/english/standards/relm/il c/ilc87/rep-i.htm

Statistics NZ (2012). Births and Deaths: Year ended in June 2012. Available from www.statistics.govt.nz

Yates, S. and Payne, M. (2006). Not so NEET? A Critique of the Use of 'NEET' in Setting Targets for Interventions with Young People. Journal of Youth Studies. 9 (3), 329-344. 